\title{
Huisarts werkt in de toekomst wijkgericht
}

\author{
Maria van den Muijsenbergh, Henk Schers, Pim Assendelft
}

\author{
Wijkgericht werken lijkt de nieuwe panacee. Maar wat is het? Werkt het? En wat moet de huisarts \\ ermee?
}

\begin{abstract}
Wijkgericht werken staat sterk in de belangstelling, zo blijkt uit het recente dubbelinterview met de hoogleraren Bindels en De Wit in dit blad. ${ }^{1}$ Het onderwerp speelt ook binnen de denksessies over de toekomst van de huisartsenzorg, die momenteel door de beroepsgroep worden georganiseerd. Maar voor veel huisartsen is onduidelijk wat precies verstaan wordt onder wijkgericht werken en wat er van hen in de toekomst verwacht wordt. Gebaseerd op onderzoek en ervaring is onze visie dat het een groot potentieel heeft om gezondheid en welbevinden van de meest kwetsbare burgers te verbeteren. Voor ons is de vraag niet óf huisartsen wijkgerichte zorg moeten leveren, maar hóe.
\end{abstract}

\section{NIKS NIEUWS}

Het organiseren en leveren van zorg en ondersteuning zo dicht mogelijk bij huis is voor huisartsen niks nieuws. De term 'wijkgericht werken' is in Nederland sinds een jaar of tien in zwang geraakt vanuit overheid, gemeente en welzijn, waarbij het niet alleen gaat om individuele zorg en ondersteuning dicht bij huis, maar ook om gezondheidsbevordering. ${ }^{2,3}$ Het doel hierbij is om zorg-en dienstverlening lokaal en in samenhang te organiseren.

\section{Wijkgerichte, integrale zorg kan gezondheid en welbevinden van de meest kwetsbare burgers verbeteren}

\footnotetext{
Op het gebied van wonen, welzijn en zorg vindt daarom samenwerking plaats. Door zorg en ondersteuning dichter bij mensen te brengen, kunnen (gezondheids)problemen worden voorkomen, of sneller, effectiever en goedkoper worden opgepakt door de mensen zelf of, indien nodig, door zorgverleners. ${ }^{4}$

Dit betekent dat wijkgerichte zorg twee doelen heeft: de integrale benadering van problemen van patiënten én het bevorderen van de gezondheid van de inwoners, onder andere door preventie. Op individueel niveau
}

verstaan we onder integrale benadering dat de huisarts of andere hulpverlener aandacht heeft voor álle problemen van de patiënt. Op wijkniveau betekent integraal dat gezondheidszorg en sociaal domein hun activiteiten combineren en op elkaar afstemmen, om zo samenhangende, toegankelijke zorg en ondersteuning te bieden. ${ }^{5}$

\section{PERSOONSGERICHTE, INTEGRALE BENADERING}

Gezondheidsproblemen hebben niet alleen betrekking op de medische conditie, maar ook op sociale en fysieke omgevingsfactoren. De kernwaarden van de huisarts indachtig is het voor ons - en voor de meeste huisartsen - vanzelfsprekend dat de huisarts een persoonsgerichte, integrale benadering van de patiënt kiest. ${ }^{6}$ Dat betekent aandacht voor alles wat de patiënt naar voren brengt en voor diens psychosociale context. Vooral mensen die minder in staat zijn zelf hun zorg te vinden (lage gezondheidsvaardigheden, lage opleiding) komen met al hun zorgen bij de huisarts, ook met sociale problemen. ${ }^{7} \mathrm{Om}$ hen ook bij deze problemen de weg te kunnen wijzen, is kennis van en samenwerking met organisaties in de buurt op het gebied van sociale ondersteuning onontbeerlijk.

\section{MINDER BELASTING HUISARTSEN}

Al lang is de meerwaarde bekend van de rol van de eerste lijn in wijkgericht werken. ${ }^{8}$ Het recentst laat 'Krachtige basiszorg' in de Utrechtse wijk Overvecht zien dat een integrale, wijkgerichte aanpak winst oplevert: voor betrokken professionals (huisartsen voelen zich minder belast) en voor de zorg (minder verwijzingen naar de tweede lijn). ${ }^{9}$ Ook leefstijlinterventies zijn het effectiefst als zij worden ondersteund door een breder gezondheidsbeleid, gericht op de hele wijk of gemeenschap. ${ }^{10}$

\section{TAAK EN GRENS HUISARTS}

De overtuiging leeft breed onder beleidsmakers en andere zorgaanbieders dat we als huisartsen meer toe moeten naar het bevorderen van gezondheid en voorkomen van ziekten. Toch twijfelt de huisarts soms: is dit wel mijn taak, en waar ligt de grens? Ongunstige omgevingsfactoren, bijvoorbeeld chronische stress door financiële problemen, vormen een belangrijk gezondheidsrisico en dragen bij aan ongezonde leefstijl. ${ }^{11}$ Juist daarom is 


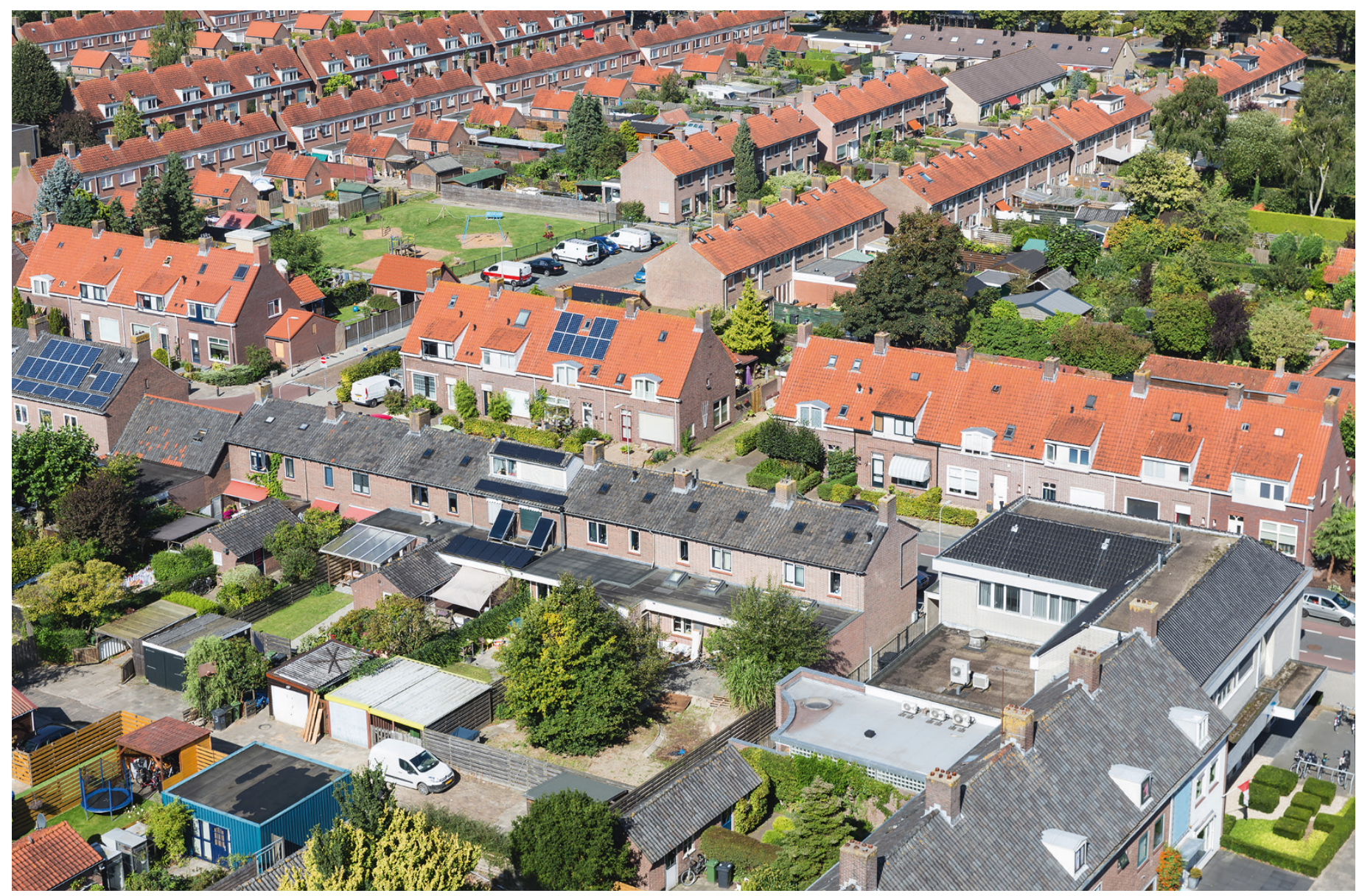

De vraag is niet óf huisartsen wijkgerichte zorg moeten leveren, maar hóe.

Foto: Shutterstock

de rol van de huisarts zo belangrijk: door zijn kennis van de context kan hij aandacht voor deze factoren combineren met persoonsgerichte ondersteuning van gedragsverandering voor een gezonde leefstijl. Uit een recent systematisch Nederlands literatuuroverzicht blijkt dan ook dat huisartsen een belangrijke rol hebben in het bevorderen van gezonde leefstijl. Juist bij mensen met een lage sociaal-economische status, bij wie de prevalentie van roken en overgewicht het hoogst is, terwijl zij de huisarts frequent bezoeken. ${ }^{12}$ Door de langdurige relatie

\section{Men zoekt vaak vooral samenwerking}

\section{en steun}

met de patiënt en de kennis van de patiëntenpopulatie is de huisarts bij uitstek in de positie om bij te dragen aan preventie. ${ }^{13}$ Huisartsen kunnen als geen ander met relatief weinig inspanning grote meerwaarde leveren, omdat voor effectieve preventie een lange adem nodig is: mensen stoppen en vallen terug, maar uiteindelijk lukt het vaak wel. ${ }^{14}$ Samenwerking tussen de individugerichte gezondheidszorg, de sociale zorg en de publieke gezondheidszorg is ook hier van belang. Huis- artsen kunnen bijvoorbeeld een ongezonde leefstijl signaleren en verwijzen naar een kookcursus of loopgroepje in de wijk..$^{15}$ En waar het gaat om kennis van de gezondheidstoestand van wijkbewoners, de wijkgezondheidsprofielen, hebben huisartsengegevens een grote toegevoegde waarde naast GGD-gegevens. ${ }^{16}$ In de GGD-enquête onder de bevolking in Nijmegen-Noord bijvoorbeeld zei 3\% van de gezinnen opvoedingsproblemen te hebben, maar uit de huisartsenregistratie in diezelfde wijk bleken deze problemen te spelen bij maar liefst 17\% van de gezinnen: reden voor de jeugdgezondheidszorg om hieraan dus meer aandacht te gaan besteden.

\section{HUISARTS ALS SAMENWERKINGSPARTNER}

Op veel plaatsen zijn huisartsen actief in een wijkgerichte, integrale aanpak zoals in het Utrechtse Overvecht, Nieuwegein met Welzijn op recept (https://welzijnoprecept.nl) en Deventer (www.samengezondindeventer.nl/projecten/gezondheid-en-gedrag). ${ }^{17}$ LHV en NHG ondersteunen huisartsen daarin, onder andere met het project Preventie in de buurt (www.nhg.org/preventieindebuurt), de werkmap Huisarts en gemeente - samenwerken in de wijk en de recent verschenen NHG-Praktijkhandleiding Samenwerken aan gezondheid in de wijk. ${ }^{18}$ NHG en LHV noemden al in 2012 in de Toekomstvisie 2022 integrale, wijkgerichte zorg en preventie expliciet als uitgangspunt voor de huisartsenzorg. ${ }^{19}$ 
Huisartsen moeten als samenwerkingspartner in een wijkgerichte, integrale aanpak per onderwerp aangeven hoe en in welke mate zij bij de wijkinfrastructuur betrokken willen en kunnen worden: geïnformeerd (graag laten horen als er iets speelt), afgestemd (voorafgaand overleggen dat iets eraan komt), betrokken (huisarts doet als een van de partijen mee) en ten slotte de 'zwaarste' vorm van participatie: verantwoordelijk (de huisarts is aanspreekbaar op de uitvoering en het resultaat). Het is niet zo dat anderen altijd van huisartsen verwachten dat deze ook 'verantwoordelijk' zijn: men zoekt vaak vooral samenwerking en steun, en dat kan dus op vele manieren. Samenwerkingsvragen spelen soms op het niveau van de wijk of HAGRO, soms in een gemeente of regio en soms vooral landelijk (zoals preventie-akkoorden). Omdat de andere partijen vaak niet weten bij wie ze op welk niveau moeten zijn, kloppen ze soms willekeurig op de deur van de individuele huisarts, waardoor die inderdaad de indruk kan krijgen dat ze hem overal voor moeten hebben. Per onderwerp kan echter bekeken worden of het gesprek wel uit moet gaan van de individuele huisarts of huisartsenpraktijk, en waar nodig moet worden verwezen naar regionale of landelijke bestuurders.

\section{GUNSTIGE TIJD VOOR WIJKGERICHTE ZORG}

De tijd lijkt gunstig voor preventie en wijkgerichte zorg door de huisarts. Het kabinet maakt zich sterk voor preventiecoalities en lokaal worden tussen verzekeraars en gemeenten ook al preventieakkoorden gesloten. Met de komst van de GLI (gecombineerde leefstijlinterventie) per 1 januari 2019 wordt het belang van preventie ook vanuit de zorgverzekeraar benadrukt, en komen er gelden beschikbaar voor vervolgzorg voor leefstijl in de wijk. Hierbij is het belangrijk dat er straks niet alleen ziekenhuisleefstijlpoli's en commerciële leefstijlcoaches komen, die zich zonder overleg of afstemming gaan bezighouden met preventie, met het risico dat de context van de patiënt uit het oog verloren wordt.

Daarnaast bieden de nieuwe tarieven voor het stimuleren van de Organisatie en Infrastructuur in de eerste lijn (O\&I) kansen, zoals het tarief voor wijkmanagement. Een voorwaarde voor het kunnen declareren van dit tarief is dat er afspraken met professionals uit het sociale domein gemaakt worden. Dit heeft geleid tot veelbelovende initiatieven, onder andere in Zwolle, waar de regionale ondersteuningsstructuur de randvoorwaarden creëert en een palet aan mogelijke projecten presenteert waaruit de huisartsen per wijk kunnen kiezen. ${ }^{20}$ Deze ontwikkelingen bieden kansen voor de verdere invulling van de rol van de huisarts in de wijk, mede gezien onze ervaring dat het van cruciaal belang is om verantwoordelijkheden en organisatie goed te beleggen. Wij hebben in Nijmegen de nodige ervaring opgedaan met de organisatie van wijkgerichte zorg met behulp van wijkgezondheidsprofielen. Professionals, waaronder huisartsen, waren vaak enthousiast om op deze manier naar 'hun' wijk te kijken en gezamenlijk problemen aan te pakken. Vaak werd prioriteit gelegd bij preventieve activiteiten, maar vooral de organisatie (wie is verantwoordelijk) en aansturing bleek na de projectfase uitermate lastig te regelen.

Naar onze overtuiging zou je wijkgericht werken daarom qua randvoorwaarden op regionaal niveau moeten organiseren. Als dit bestuurlijk goed wordt opgepakt, dan zal de huisarts in zijn praktijk in de toekomst ontlast worden van de vele vragen en verzoeken die momenteel vanuit gemeente en welzijnsdomein tot hem komen. Zo zal er meer helderheid komen over de rol van de individuele huisarts.

\section{CONCLUSIE}

Voor ons is de vraag niet óf huisartsen wijkgerichte zorg moeten leveren, maar hóe. Wijkgerichte preventie en integrale zorg hebben een groot potentieel om gezondheid en welbevinden van juist de meest kwetsbare burgers te verbeteren. Dit kan zich bij goede planning en uitvoering vertalen in werkdrukvermindering en meer satisfactie van de huisartsen. In het huidige politieke klimaat is er steun van de lokale en landelijke overheid alsmede de verzekeraars te verwachten. 'Win-win' in de wijk dus - wat willen we nog meer?

\section{LITERATUUR}

1. Veenstra T. Hoogleraren De Wit en Bindels in discussie over wijkgerichte zorg. Huisarts Wet 2018;61(8):30-2.

2. Organisatorische samenwerkingsverbanden binnen de eerste lijn een inventarisatie. Utrecht: NIVEL, 2009.

3. Zorg en ondersteuning in de buurt. Den Haag: Ministerie van Volksgezondheid, Welzijn en Sport, 2011.

De volledige literatuurlijst staat bij dit artikel op www.henw.org.

Van den Muijsenbergh METC, Schers HJ, Assendelft WJJ. Huisarts werkt in de toekomst wijkgericht. Huisarts Wet 2018;61[10]:41-3. D0I: 10.1007/s12445-018-0296-8.

Radboudumc, afdeling Eerstelijnsgeneeskunde, Nijmegen: prof.dr Maria E.T.C. van den Muijsenbergh, huisarts, bijzonder hoogleraar Gezondheidsverschillen en persoonsgerichte integrale eerstelijnszorg, tevens werkzaam bij Pharos, expertisecentrum gezondheidsverschilIen, Maria.vandenMuijsenbergh@radboudumc.nl; dr. Henk J. Schers, huisarts, senior-onderzoeker; prof.dr. Willem J.J. Assendelft, hoogleraar Huisartsgeneeskunde.

Belangenverstrengeling: MvdM werkt bij Pharos, expertise gezondheidsverschillen, en bij het programma wijkgerichte zorg van Radboudumc, afdeling Eerstelijnsgeneeskunde. Bij beide organisaties is zij betrokken bij het initiëren en uitvoeren van onderzoek naar voorwaarden voor en opbrengsten van wijkgerichte, integrale zorg. 